Editorial

\title{
Leadership and Change in Asia-Pacific: Where Does Political Will Come From?
}

\author{
David Hudson ${ }^{1, *}$, Nicolas Lemay-Hébert ${ }^{2}$, Claire Mcloughlin ${ }^{1}$ and Chris Roche ${ }^{3}$ \\ ${ }^{1}$ International Development Department, School of Government, University of Birmingham, Birmingham B15 2TT, UK; \\ E-Mails: d.e.hudson@bham.ac.uk (D.H.), c.mcloughlin@bham.ac.uk (C.M.) \\ 2 Department of International Relations, Coral Bell School of Asia Pacific Affairs, Australian National University, Canberra, \\ ACT 2600, Australia; E-mail: nicolas.lemay-hebert@anu.edu.au \\ ${ }^{3}$ Institute for Human Security and Social Change, La Trobe University, Melbourne, VIC 3086, Australia; \\ E-Mail: c.roche@latrobe.edu.au \\ * Corresponding author
}

Submitted: 10 November 2020 | Published: 25 November 2020

\begin{abstract}
We introduce this thematic issue by exploring the role of leadership in social and political change. In current times, the importance of leadership and choice has proved as important as ever. Leadership is often the critical variable separating success or failure, legitimacy and sustainability or collapse. This thematic issue explores a range of in-depth case studies across the Asia-Pacific region that help illustrate the critical elements of leadership. Collectively they demonstrate that leadership is best understood as a collective process involving motivated agents overcoming barriers to cooperation to form coalitions that have enough power, legitimacy and influence to transform institutions. Five themes emerge from the thematic issue as a whole: leadership is political; the centrality of gender relations; the need for a more critical localism; scalar politics; and the importance of understanding informal processes of leadership and social change.
\end{abstract}

\section{Keywords}

Asia-Pacific region; China; Covid-19; developmental leadership; Fiji; India; Indonesia; Papua New Guinea; political will; Solomon Islands

Issue

This editorial is part of the issue "Leadership and Political Change in Asia-Pacific" edited by David Hudson (University of Birmingham, UK), Nicolas Lemay-Hébert (Australian National University, Australia), Claire Mcloughlin (University of Birmingham, UK) and Chris Roche (La Trobe University, Australia).

(C) 2020 by the authors; licensee Cogitatio (Lisbon, Portugal). This article is licensed under a Creative Commons Attribution 4.0 International License (CC BY).

\section{Introduction}

We introduce this thematic issue by exploring the role of leadership in social and political change. Change always happens through the interaction between individuals and the institutional context they inhabit (or agency and structure). Leadership is at the heart of this process; and to understand it we must take a dynamic view of how incentives, values, interests and opportunities motivate individual leaders and groups to push, or resist, change.
Leadership is a collective process where motivated agents must overcome barriers to cooperation to form coalitions that have enough power, legitimacy and influence to transform institutions in a positive (developmental) way. This thematic issue sheds light on how this process can unfold, using a range of in-depth case studies across the Asia-Pacific. Collectively, the seven articles help address the question of where 'political will' comes from, where political will is redefined as a process of contestation at the individual, collective and societal levels. 


\section{Why Leadership, Why Now?}

When we originally planned this thematic issue on the topic of leadership, we could never have imagined that it would be published in the midst of a global pandemic; a time when leaders around the world are facing the most extraordinary test. Addressing the devastating effects of Covid-19 effectively has called on state and non-state authorities to make and enforce extraordinary rules, ensure citizen compliance with them, and plan and implement highly complex, unforeseen public health and economic interventions.

We have witnessed much variation, both across and within countries, in rising to this challenge. While academic analysis remains nascent, researchers are beginning to examine the relationship between how well countries have performed in response to Covid-19 and preexisting levels of institutional development, political systems, economic wealth, geography, demographics and cultural factors. But it is apparent that these cannot provide a complete explanation. Some of the worst performing countries in the world, with the highest rates of infection per capita, also have some of the highest GDP (the US, for example). And while political institutions might matter, there are fewer clear patterns between, for example, authoritarian or democratic regimes in their handling of the crisis than we might expect.

Leadership matters, ultimately, because institutions do not respond to pandemics; people do. That said, as we have seen in the response to the global pandemic, leaders respond to crisis in ways that reflect the institutions and incentives in which they are embedded, constrained and enabled by. A myriad of everyday decisions are now being taken, sometimes for the greater good and sometimes self-serving, by people with power. By people who are either bestowed with, or who are claiming, the space to act.

The outcomes of these choices will not always be foreseen or intended. The complexity and globality of the pandemic and the dependencies within and between human societies means they will be radically non-linear. What is certain is that we will have to live with the institutional legacies of choices that are not obviously rational or desirable. Understanding the dynamics of leadership is arguably more important now than ever, if we want to understand what enables or constrains complex problem-solving in crisis, but more broadly, what can enable or constrain social change.

\section{From Leaders to Developmental Leadership}

Our argument here, and elsewhere, is that we cannot unpack the leadership complex by exclusively examining leaders' choices and actions. For more than ten years, research from the Developmental Leadership Program (DLP) has investigated the political dynamics of leadership (Hudson, Mcloughlin, Roche, \& Marquette, 2018). The findings stress that leadership is not an individu- al phenomenon that happens inside politicians' heads. Leaders cannot pursue real change without influencing people, or persuading them to change their ideas or behaviours. Leadership is always, everywhere, an interaction between leaders and followers (Hudson \& Mcloughlin, 2019). Political 'will' isn't something that can be conjured up, literally 'at will' by individuals and then change happens. The necessary ingredients and process that change happens through is one that is often deeply political and uncomfortable and is fundamentally about contestation. By contestation we mean that motivations, interests, ideas, goals and plans need to be formulated, challenged, and compromised-and it is only through such a process that political will can be built. As such political will is something that is built collectively and involves coalitions and deals, it includes followers as much as leaders, or constellations of leaders across the political spectrum and across different spaces and scales. These are issues that a number of the articles in this thematic issue elaborate upon.

Critically, it is also true that leaders are never entirely free from rules that constrain or restrain them. In the real world, change hinges on the complex relationships between individuals and the norms and rules they inhabit.

\section{Leadership at the Individual, Collective and Societal Level}

Elsewhere we have argued that political will for positive change can be achieved through a process of 'developmental leadership' (Hudson et al., 2018). Developmental leadership is a collective, strategic and political process through which people contest institutions and make change happen. It is typically messy, protracted, and beset by dead ends and reversals. But ultimately it always works via three core elements coming together at the individual, collective and societal levels. At the individual level, developmental leadership functions through motivated and strategic individuals. These individuals have some set of incentives, values, interests and opportunity to push for change-in short, motivation. But motivation is not enough. And this is the point: Even the most motivated need a combination of power and opportunity to realise their goals, as well as the skill to work strategically.

Second, as noted, because political will is collective not individualistic, developmental leadership requires barriers to cooperation be overcome and coalitions formed. And these coalitions must have sufficient power, legitimacy and influence. The effectiveness of such coalitions depends upon the political strategies and tactics they use, their perceived local legitimacy, the work they do behind the scenes, and ultimately, their pragmatism. Critically, coalitions can be very mixed, made up of those who are intrinsically committed to reforms, but also often include those who are more instrumental or opportunistic. 
Third, and critically, an effective (and powerful) coalition boils down to their ability to contest and delegitimise one set of ideas and legitimise an alternative set. Time and again, ideas, rules and norms of how the world should operate and be ordered is the most significant barrier to change. The work of developmental leadership, and the coalitions that support it, is to challenge, contest and change the ideas that structure society. Doing so, and crucially via ways that are perceived as locally legitimate, ensures that such change is more likely to be sustainable. Contests over the myths, narratives and frames that people view the world about what's fair and right for society become the critical ground that political will is built on, or evaporates.

\section{Emerging Themes: Political Leadership, Gender, Critical Localism, Informal Social Change and Scales}

The thematic issue begins from this understanding of leadership as collective, political and contextual and offers a broad range of case studies straddling the Asia-Pacific region. Roche, Cox, Rokotuibau, Tawake, and Smith (2020) and Craney (2020) cover the Pacific, with case studies from the Solomon Islands, Papua New Guinea as well as a Pacific regional initiative ('Green Growth Coalition'). Lin (2020) analyses technocratic leadership in the People's Republic of China, Krishna and Roche (2020) and Gordon (2020) look at India. Finally, Sherlock (2020) and Hudson, Mcloughlin, Margret, and Pandjaitan (2020) discuss cases from Indonesia.

Five main themes emerge from these debates and the thematic issue as a whole: leadership as political; gender relations; critical localism; scalar politics; and the value in understanding informal processes of leadership and social change.

The first theme that appears clearly in the issue is the political nature of leadership, and a number of crucial contributions are made on this theme. Lin (2020) looks at the role of political capital to explain the rise of a provincial technocratic elite in China in the 1990s. As such, Lin makes a contribution to the political technocracy theory, understanding this rise as an effective alliance of technocrats and career bureaucrats. Craney (2020) looks at 'locally led development' through an informal elite network lens, problematizing simplistic understandings of what constitutes the local in that respect. Gordon (2020) contributes to the 'transformative leadership' discussion, understanding how actors operating outside of traditional politics manage to bring effective social change through their actions. Krishna and Roche's (2020) analysis makes a crucial contribution to the understanding of political will as being contingent upon leadership at the individual, collective and societal levels. And Hudson et al. (2020) offer new empirical evidence for how political leaders are evaluated, supporting the social identity theory of leadership in a non-Western setting (Indonesia precisely). They show how individual leaders who best reflect and represent the identity of the group tend to be more trusted and have more leeway in how they are perceived as effective or not.

The second theme appearing clearly in this thematic issue is gender relations and leadership. Through their focus on Simbo for Change, an initiative in the Western province of the Solomon Islands, Roche et al. (2020) bring to light the leadership of the director of the initiative, Esther Susi, and the notion of 'quiet feminism' showing how the initiative she led re-articulated women's empowerment as an essential part of creating a cohesive a broader island identity. Gordon (2020) looks at what motivates women to become leaders in their own communities through an analysis of a grassroots microfinance organisation called Rojiroti in India. Because of their own positions in their communities, women leaders were best placed to tackle a number of issues and managed to display 'transformative leadership' in doing so. As such, through their active involvement in this social process, Rojiroti's women leaders were able to challenge rather than perpetuate the existing inequalities. Moving up scales, Sherlock (2020) looks at how civil society organisations working for women's empowerment and gender equality in Indonesia have managed to influence members of parliament to adopt positions that would end up being of mutual benefit to both actors.

The third theme explicitly discussed in this thematic issue revolves around the concept of 'critical localism' and leadership. Localism is too often easily accepted and valorised. Roche et al. (2020) question the concept of the local, especially when constructed as an unhelpful binary opposition to a vague concept of the international. They call for more attention to be paid to 'critical localism,' this is exploring the vernacular understandings of the local and the complex webs of power in which different 'local' actors are located. Similarly, Craney (2020) questions the assumption made by donors and multilateral organisations about who is included in the concept of the 'local,' arguing that a diversity of voices and experiences should be captured. Gordon (2020) similarly sheds light on the complex landscape that are constituted by local politics through a thicker understanding of what 'grassroots' leadership is about.

The fourth theme is around scalar politics. The thematic issue as a whole stresses the importance of 'multiscalarity,' understood as the constant interaction between different scales of analysis: the global, the regional, the national, and the local. Roche at al. (2020) point out not just this 'vertical' scaling, but also the importance of 'horizontal' linkages in the Pacific which illustrate the role of support from with the region, which can be more relevant and culturally appropriate than international linkages from outside the region. As previously mentioned, Sherlock (2020) adopts a scalar approach through the interplay between grassroots and national politics. For us this is a critical avenue for future research: How leaders and leadership effectively works through and across different scales, and the politics of that. 
The final theme relates to what fluid and informal processes of social change tell us about more deliberate attempts to support individual and collective leadership. Craney (2020) and Roche et al. (2020) provide examples of collective action from the Pacific which demonstrate characteristics which are very much at odds with the more formal projectized approaches that tend to dominate the world of international development. Gordon (2020) also points to similar distinct facets of leadership amongst grassroots women's organisations in India in generating mutual support and solidarity. Sherlock (2020) illustrates how women's civil society organisations in Indonesia, whilst supported by a large development program, have at the same time worked politically with members of parliament to build 'alliances of instrumental advantage.' These articles provide a useful reminder of how decentring the world of formal institutionalised development can reveal not only how more immanent processes of social change occur, but also the shortcomings of more deliberate, intentional project based attempts to promote leadership. Essentially, those who want to provide effective support to leadership processes will need to let go. Not a comfortable proposition. But one that cannot be ignored.

\section{Acknowledgments}

We thank the Australian Department of Foreign Affairs and Development, University of Birmingham, and La Trobe University for their financial contributions and partnership that supports the work of the Developmental Leadership Program. We also thank the editorial team at Politics and Governance in helping get this thematic issue over the line in extraordinarily difficult times.

\section{Conflict of Interests}

The authors declare no conflict of interests.

\section{References}

Craney, A. (2020). Local participation or elite capture in sheep's clothing? A conundrum of locally led development. Politics and Governance, 8(4), 191-200.

Gordon, R. (2020). Transformative grassroots leadership: Understanding the role of Rojiroti's women leaders in supporting social change. Politics and Governance, 8(4), 180-190.

Hudson, D., \& Mcloughlin, C. (2019). How is leadership understood in different contexts? (DLP Foundational Paper No. 1). Birmingham: Developmental Leadership Program.

Hudson, D., Mcloughlin, C., Margret, A., \& Pandjaitan, Y. (2020). Leadership, identity and performance: The nature and effect of 'prototypicality' in Indonesia. Politics and Governance, 8(4), 201-213.

Hudson, D., Mcloughlin, C., Roche, C., \& Marquette, H. (2018). Inside the black box of political will: 10 years of findings from the Development Leadership Program. Birmingham: Developmental Leadership Program.

Krishna, U., \& Roche, C. (2020). Locating leadership and political will in social policy: The story of India's MGNREGA. Politics and Governance, 8(4), 168-179.

Lin, R. (2020). The rise of technocratic leadership in the 1990s in the People's Republic of China. Politics and Governance, 8(4), 157-167.

Roche, C., Cox, J., Rokotuibau, M., Tawake, P., \& Smith, Y. (2020). The characteristics of locally led development in the Pacific. Politics and Governance, 8(4), 136-146.

Sherlock, S. (2020). Alliances of instrumental advantage: Supporting women's agency in civil society organisations in Indonesia. Politics and Governance, 8(4), 147-156.

\section{About the Authors}

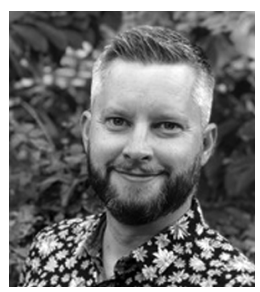

David Hudson is the Professor of Politics and Development in the International Development Department at the University of Birmingham. David's work focuses on the politics of development, in particular on the role of coalitions, leadership and power in reform processes and how development actors can think and work politically as part of the Developmental Leadership Program, migration and migration-decision making, and how people in rich countries engage with global development issues as part of the Development Engagement Lab.

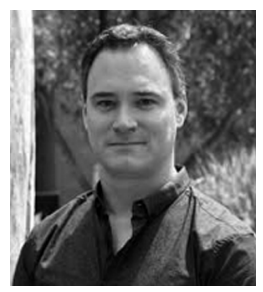

Nicolas Lemay-Hébert is a Fellow in the Department of International Relations, Australian National University, and the Department's Director of Research. His current research interests include statebuilding and intervention issues in Asia-Pacific and beyond. He is particularly interested in local resistance to international interventions and the political economy of interventions. 

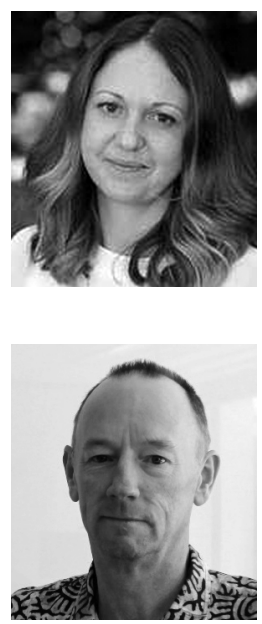

Claire Mcloughlin is Lecturer in Political Sociology in the International Development Department at the University of Birmingham. Claire's research focuses on the political sociology of vital public service delivery in conflict-affected and divided societies. In particular, she is interested in the politics of distributive justice and procedural fairness in service delivery, and the historical processes that embed welfare provision in social contracts. Claire currently conducts research on the politics of development and leadership for the Developmental Leadership Program, for which she acts as Deputy Director (Research).

Chris Roche is Professor of Development Practice at La Trobe University, in Melbourne, Australia, and Director of the Institute for Human Security and Social Change. Chris is also Deputy Director (Impact) of the Developmental Leadership Program. 